STATE OF ILLINOIS

DEPARTMENT OF REGISTRATION AND EDUCATION

DIVISION OF THE

NATURAL HISTORY SURVEY

STEPHEN A. FORBES, Chef

\begin{tabular}{lll}
\hline Vol XVII. BULLETIN & Article IX. \\
\hline
\end{tabular}

\title{
Methods and Principles for Interpreting the Phenology Crop Pests
}

$\mathrm{BY}$

L. R. TEHON

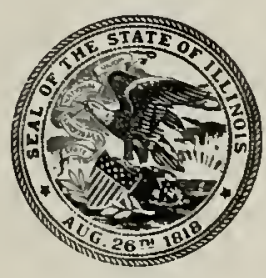

PRINTED BY AUTHORITY OF THE STATE OF ILLINOIS

\section{URBANA, ILLINOIS}

July 1928

Reprinted 1931 
STATE OF ILLINOIS

DEPARTMENT OF REGISTRATION AND EDUCATION

A. M. SHelton, Director

BOARD OF

NATURAL RESOURCES AND CONSERVATION

A. M. Sheltos, chairman

WillaA TRELEASE, Biology

Hexry C. Cowles, Forestry

Eisox S. Bistix, Geology

William A. NoYes, Chemistry
John W. Aliokt, Engineering

Charles M. Trompsox, Representing the President of the University of Illinois

THE NATURAL HISTORY SURVEY DIVISION

Stepinex A. Forbes, Chief

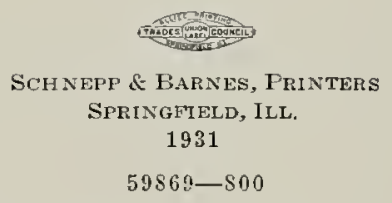




\title{
METHODS ANI PRINGIPLES GOR INTHR- PRETING 'THE, PHENOLOGY' OF CROP IPESTS*
}

\author{
L. R. Tehon
}

\section{INTRODLCTION}

The dominating influence exerted by weather and climate in determining the occurence and distribution of phytopathogenes and phytophages, as well as the extent and the intensity of their attacks, is so comspiciously self-manifesting that it receives universal recognition : and nuch effort has been expended in trying to determine experimentally. with the airl of accurately regulated laboratory devices, the manner in which temperature and moistme, the two chief elements, operate. While such work has an inestimable erudite value, much so learned is, at present at least and from the practical standpoint, to a very large extent incapaible of being applied to the inmerliate and pressing problems of the farm and orcherel.

For this, there appears to be a fair justification; for the investigator, trained to methods inseparable from the nicrosone, the test tube, and the precision of apparatus and reagent, as well as being greatly restrained la the demands of the varied tasks of teaching and agricultural exten ion, can attack this problem only with the resources at his command, and the essential background furnisher by an intinate knowledge of the conditions under which organisms exist naturally remains, as a result, unilluminated. Another consequence is that there are few metheds known ly means of which geographical and seasonal variations. whether in numbers or other characters, exhibited ly pests coincidentally with clinatic variations or the weather of an enviromment can be expressed and explained.

There is need, therefore, of more extensive and complete linowlerlge of clistribution, of the extent and intensity of plant diseasc and insect invasions, and especially of snitable means to express these things exactly in their relation to climate and to weather. kecently, through the l'lant Disease and lnsect Surveys of the L. S. Department of . Igriculture and similar separate or cooperating agencies in several states, a start has been

* The material given under this titlo constitutes an enlargement and revision of a paper previonsly prepired but never published, except in an abstracted form fset: Tehon, I. IR. The field survey as a basis for the phenological inturpretation of the linnt disease ellidemic, Phytopatholugy 16: 63. 1926).

The term phenology is used so rarely ly plant pathologists that l venture to define it, briefy, as the study which rengnizes the effects of weather and cimate in deternining the lime of appearance of phenomena, or events, in mature and seeks to define their influence exactly. 
made with the first task: and the ultimate value of their accomplishments will depend not merely upon the success with which they record distribution. but (as it seems to the writer) more particularly upon the progress they make with the second task, by measuring and reporting, in understandable and comparable terms, periodic and seasonal fluctuations in abundance and intensities of attack. The third task, that of relating these phenomena to their particular meteorological accompaniments, naturally will fall to the investigator, who, by being employed expressly for the purpose or urged thereto by his personal inclinations. finds the time and means at hand to solve these intricate problems.

In the present state of affairs, this paper proposes primarily to call attention to a method of defining the relations of plant cliseases to climate and weather: but it intends, also, to make additional suggestions which may be nseful to entomologists (the latter having used the method to a limited extent) and to point out some of the fundamental principles concerned. If certain sections of the paper should appear to readers to be lacking in conclnsiveness, the writer would respond that his aim has been not so much to draw final conclusions as to illustrate the potentialities of a method.

\section{GRAPHIC DEPICTION OF CLIMATE AND IVEATHER}

The device* here used to depict climate and weather is not new, for it appears to have been originated by Ball $(2)$ about 1910 and to have received its first application to practical problems in the hands of Taylor (1i) in 1916 ; but certain of its meanings are newly shown in the latter part of this paper. Being concerned with temperature and rainfall, it has been termed a hythergraph. A variation of it. which makes use of temperature and relative humidity, is known as a climograph, for the reason that relative humidity, resulting from the influence of light, wind, and other lesser factors, as well as heat and rain, is considered to be a more exact expression of climate; but, as records of relative humidity often are not readily available, it can not be $115 e d$ with the same facility as the hythergraph.

By referring to Figures $t$ and 5 (pp. $32 \%$ and 328 ), both of which are simple and typical examples, the hythergraph will be seen to be nothing more than a graphic diagram, its vertical scale customarily representing temperature and its horizontal scale rainfall; and any given combination of measurements relating to these elements will be shown thereon by a point located at the intersection of the proper ordinate and abscissa.

As a result of the ways in which it can be constructed, this graph will assume one or the other of two general forms, both of which are used in this paper. The simpler form consists of a series of points which mark combinations of temperature and rainfall for successive days or for longer

* An interesting discussion, with suggestive notes, is contained in an article by V. E. Shelford, with the title "Physiological life histories of terrestrial animals and modern methods of representing climate" which occurs in the Transactions of the Illinois State Academy of Selence, vol. 13, pp. 257-271, 1920. 
periods; and the general trend from one to another of these points often is shown by connecting lines, according to Ball's suggestion, as has been done in Figure 5.

In constructing the more complicated form, a considerable number of mean temperature-total rainfall combinations for stated periods, such as months or years, or for localities or regions, are plotted in the manner illustrated by Figure 15 (p. 39\%) : and the particular range of the conditions associated with a given phenomenon, or with certain degrees of its manifestation, as indicated by correlative data, then may lie determined by joining the plotted points with straight lines. The result is usually one or a number of irregular polygons, which may be made more inclusive, and probably more indicative, by "smoothing" them by the use of mathematical formulae or, as frequently may be done with entire satisfaction when data are abundant, simply by applying the draftsman's "French curve" and making the lines indicated by it.

The two types of graplus often may be comluned advantageously, as in Figure $1 t$ (p. 336 ), to show not only the ranges but also the trenrls of months. seasons. or other desirable periods associated with a given phenomenon: indeed, the variations of which the lyythergraph is capable are so diverse that they provide almost unlimited opportunities for comparing correlative facts and so of drawing therefron inferences relating to it wide scope of inquiries.

For the sake of simplifying the language in the subseguent pages of this paper. I an suggesting two new terms, namely, thermohyet and thermohyetic, the former to designiate a conbination datum consisting of a record of temperature and of rainfall (and, by analogy, any point placed on the hythergraph to represent such a (latum). the latter to serve as an adjective replacing generally such mwieldy terms as "temperatine-rainfall", "mean temperature-total rainfall", and the like. It is obvious that the noun can be used only within strict linits; but the adjective often can be used somewhat loosely, at the same tince expressing the thought with sufficient clearness, or if it is desirable another word, thermohyetics, may be 11 sed also with a looser meaning.

\section{WE \THER IN REIATION TO THE LATE BLIGITT OF POTATOES}

As a first illustration of the use of the graphs described in the foregoing section, the relation of the late blight disease of potatoes to weather furnishes a simple and striking example, not only because the influence of weather upon the occurrence of severe ejidenics is so miniversally recognized but also because numerous attempts, ranging from the statement of opinions based upon experience (which are by no means in agreenent. superficially) to a graphical presentation of facts, have been makle to explain specifically the connection between the two.

Without attempting to furnish either an extensive citation list or an adequate review of the literature pertaining to this subject, most of which 
would be entirely outside our problem anyway, we proceed immediately to the work of Martin (13) in New Jersey, who gathered data showing the variation in severity of the anntual late blight epidenics in that State for many years and indicated their relations to the rainfall and average temperatures of the Julys of their respective years by showing graphically how far, in each case, the thermohyetic conditions departed from the normal July weather. The conclusion of Martin's work, though in several respects illuminating, was in the main lacking in definiteness, in part because the data, in the manner in which they were presented, applied only to New Jersey, and in part because the graphical method he employed was essentially a correlation graph, from which, because the location of the axes of correlation had been predetermined erroneonsly as lying along normals of temperature and rainfall for New Jersey, the scientific deductions usually expected in such a case could not be obtained.

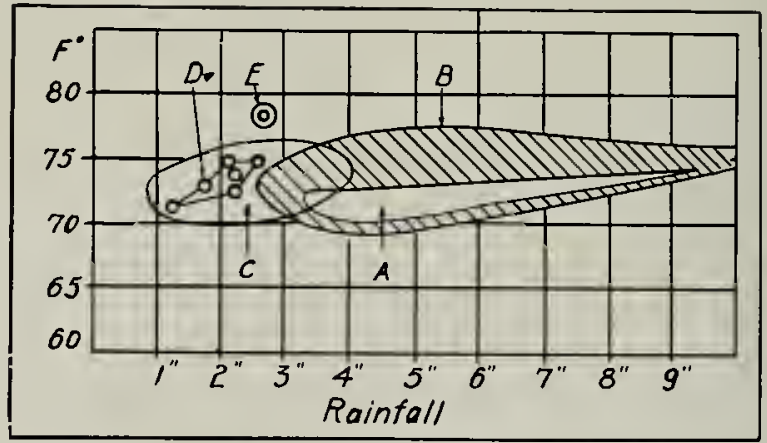

Fig. 1. Hythergraph for potato late-blight. The areas labeled $\mathrm{A}, \mathrm{B}$, and $\mathrm{C}$ mark the thermohyetic conditions conducive to severe attacks, mild attacks, and an absence of blight, respectively, as shown by Martin's New Jersey data. The points indicated by $D$ are for northern Illinois, where blight occurs but rarely; and $\mathrm{E}$ is the thermohyet for East St. Louis, where blight never occurs.

After restating Martin's data, so that they appeared as measurements of actual temperature and rainfall instead of departures from normals, it was possible to construct from them the hythergraph shown in Figure 1, in which, as directed in the foregoing section, the polygons resulting from Martin's data have been smoothed to include all the probable combinations of temperature and rainfall likely to result in heavy attacks of blight $(A)$, in light attacks of blight $(B)$, and in an absence of blight $(C)$.

It is not to be supposed that these three areas on the graph show incontrovertibly the precise limits of the thermohyetic combinations required for these respective grades of blighting; indeed, the overlapping of the region labeled $C$ upon both the regions $A$ and $B$ indicates a fatult in the 
data which would be even more apparent if the points plotted irom the clata to delineate the regions $A$ and $B$ had been retained: yet for this apparently serious discrepancy the only explanation that needs to be nade is that the type of disease data, and the sources drawn upon for them. rendered it exceedingly difficult for Nartin to make unfailingly correct classifications of his yearly records.

still. some sort of test of the general applicability of this diagram can lue made ly introducing and comvaring observations on ly light oceurrence in another region: and because of mo familiarity with Illinois, I have made this test by using facts relating to late blight in this state. Where there are two main regions in which notatoes are grown and in which the late blight disease would the the source of serions economic loss. The first lies in the somthwest, in a rather extensive territory about the city of East St. Louis, and the second. ranging throughout the northern fourth of the State. occupjes especially the north tier of counties. In the East st. Lonis region. late blight never has been known to occur: but in the north. particularly in the northeast. in JcHenry Comnty it sometines occurs in mild epidenic.. though here too. as a rule. it is absent.

It is of interest, therefore, to see what relation the themolnvetic conditions that exist in these contrasting localitien in Illinois just previous to potato harvest bear to the areas marked on our cliagram. The large dot. marked $E$ in Figure 1, represents the average weather for this period at Fast St. Louis, and from the position of this point on the diagram it is readily inferred-indeed, it seems quite self-evidont-that the wsual temperature-rainfall complement for this region differs so much from that required by the late blight disease for its development that only in the most umsual rears could this disease be expected to occur there: and. though it should. by chance, occur, its becoming either an extensive or a destructive epidemic is too remote a possibility to admit of consideration.

The northeastern region of Illinois presents. however. a different situation. and one which agrees with the facts observed. The series of points marked $D$ on the diagram represent the normal thermolnetic conditions during the period when late blight develops ior six stations in this region. In accordance with Martin's data. and with the observed fact that late blight usually does not develop here. the points all fall within the area marked $C$. the characteristic of which is that the combinations of temperature and rainfall contained by it are nut productive of late blight epidemics.

By inspecting the diagram. one readily sees. however. that the normal conditions. in the case of four of the northern Illinois stations. lie quite close to the boundary of the area $B$, defined by Martin's data. and that only slight variations in temperature and rainfall during the critical period could move these points. for a season. into the area $B$; and when this occurs (as has been olserved to be the fact) the development of a late blight epidenic is not only possible, but is, indeed, to be expected. 


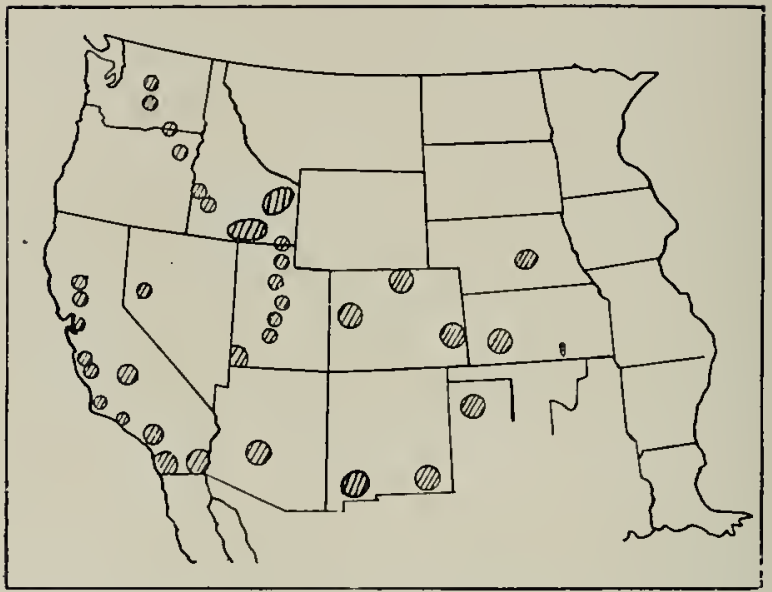

FIG. 2. Regions in which sugarbeets are infected with "curlytop". (Compiled from data by Ball and by Haskell and Wood.)

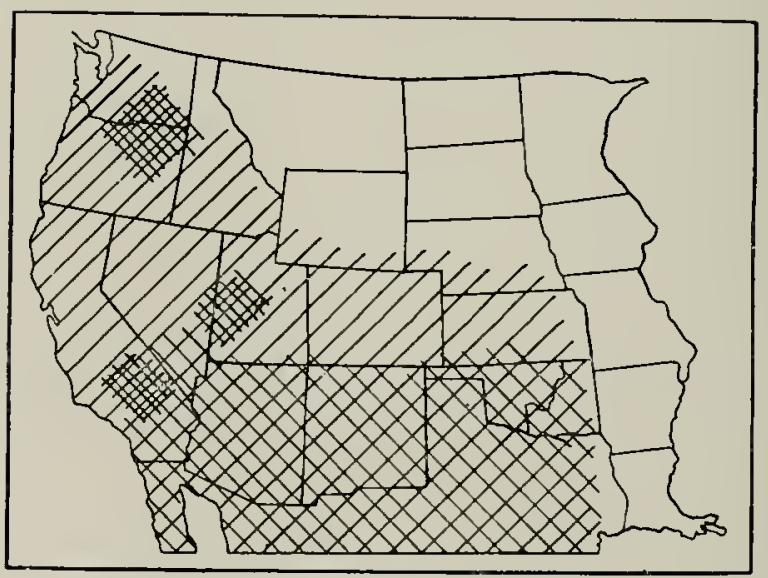

Fig. 3. Range of the beet leafhopper. Widely spaced cross hatching shows the probable natural breeding range, and the closely spaced cross hatching marks additional breeding spots from which considerable migratioll occurs. (Redrawn from Ball.) 


\section{THERMOHYETICS OF THE BEET LEAFHOPPER IND SLGARPEE'T" "CLRI.YTOP"}

"Curlytop" of sugarbeets, a virus disease carried and disseminated by the beet leafhopper, Eutctir tonclla Bak., is known to occur in epidemic proportions only in the westem and drier regions of the United States, where, according to Ball (1) and Haskel and IVood $(8)$. it has been recorded definitely in the regions shown in Figure ?: but the leafhopper, being by no means locally restricted to these regions, ranges over the very extensive territory indlicated by the rliagonal lines in Figure :

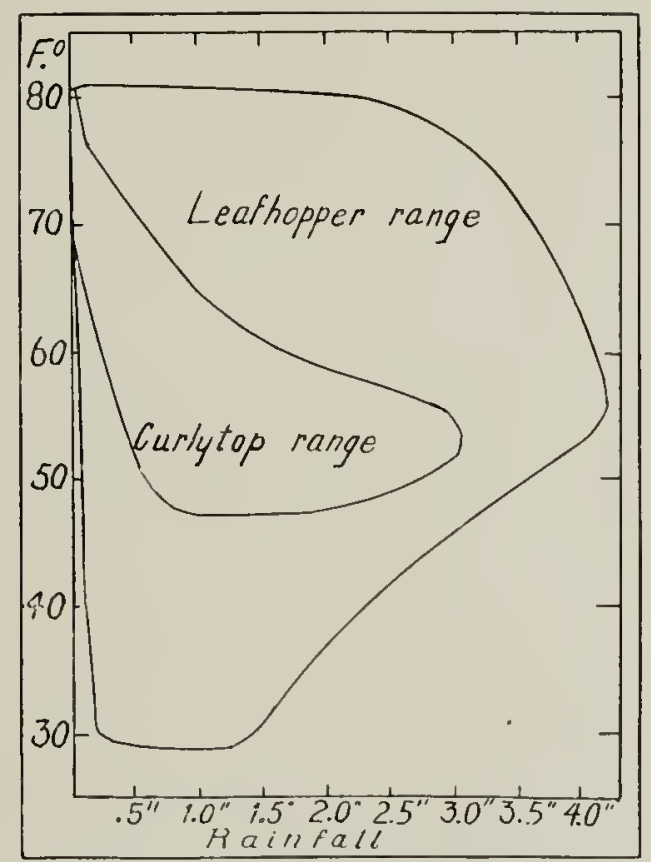

Fia. 4. Normal thermohyetic limits of the geographic ranges of the beet leafhopper and the "curlytol" disease.

sup] usedly breeding successfully throughout as much of the southern part of its range as is shown (after Ball) by the more wirlely spaced crosshatching, but breeding and nigrating in large numbers from the regions designated in the figure by the more closely spaced cross hatching.

From the records of Weather Bureau Stations situated in representative regions, one may draw a composite picture, in terms of monthly average total rainfall and normal temperature, of the year-long thermohyetic conditions which the leafhopper and the curlytop disease find suitable. The outer line in Figure 1, represents the outer linits of the annual varia- 
tions in the thermohyetic conditions associated with the geographic region throughout which the leafhopper ranges; but records from weather stations located in the neighborhood of curlytop-infested regions all fall within the inner line and give a diagram strikingly different in shape and much less extensive. Thus is it shown that the thermohyetic conditions permitting the occurrence of the disease are very definitely circumscribed as compared to those controlling the leafhopper's migratory range.

This very evident difference between the conditions that favor the insect and those that favor the disease may be illustrated in a more particular manner by comparing in Figure 5 the trend of the normal monthly thermolnyets of a locality in which only the insect abounds with those of a locality where both insect and disease occur, the localities represented being Ei Paso, Texas, and Merced, California, respectively. Since the disease appears only in the summer months, the upper part of diagram $B$ defines particularly the thermohyetic conditions necessary for its occur-

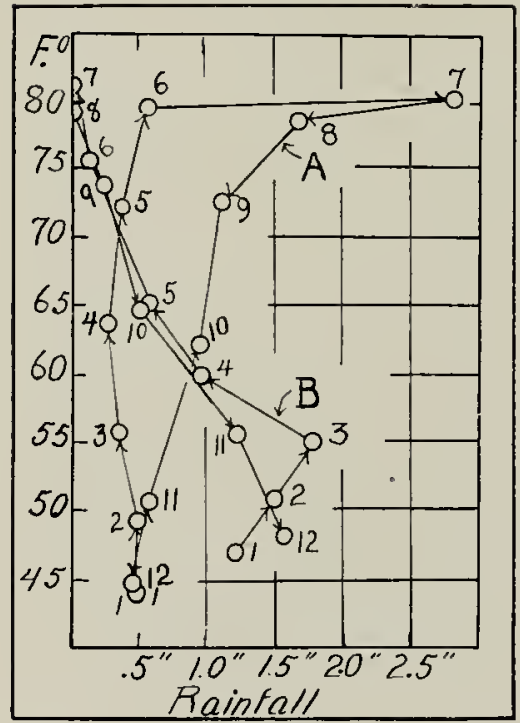

FIG. 5. Comparison of the monthly thermohyets and annual trend for El Paso, Texas, A, which lies in the range of the leaflopper only, and Merced, Cal., B, where hotl the leafhopper and "curlytop" occur. The summer season is very dry where "curlytop" abounds, but the leafhopper can thrive in a region where an appreciable anount of summer rainfall occurs:

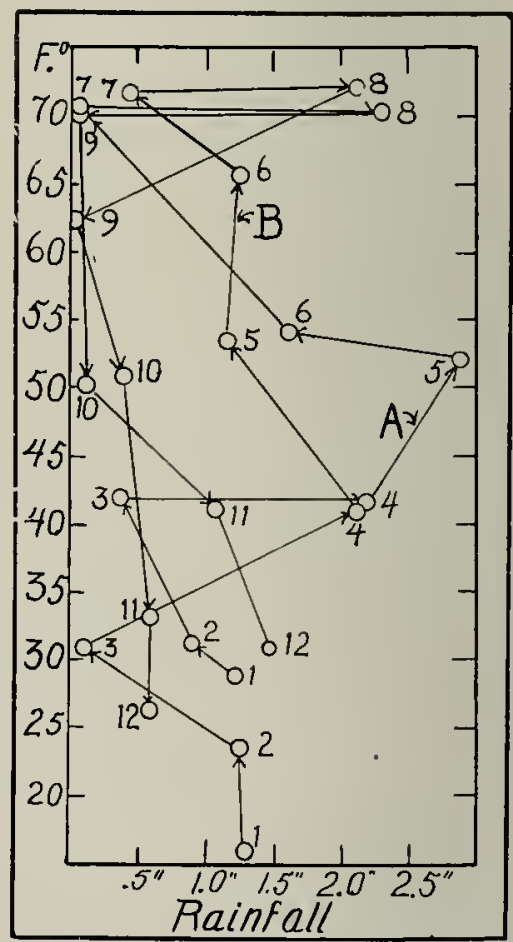

Frg. 6. Monthy thermohyets for 1921 (A) and 1922 (B) at Burley, Idaho. This locality, which lies within the range of the beet leafhopper was infested by "curlytop" in 1921, but not in 1922 . 
rence; and there is a decided contrast with those nuder which the leafhopper alone thrives, the difference apparently being a matter of summer rainfall, as a practical absence of precipitation at this time seems necessary for the disease.

Outbreaks of curlytop occur, rarely and at long intervals, in unusual situations, last a single season, and then disappear. Such an instance occurred at Burley, Idaho, in 19:1. I hythergraph for that locality, giving the monthly thermohyets for that year in comparison with those for $192 \cdot ?$ (normals are not available), is shown in Fignre 6 ; and the difference between the two diagrans emphasizes again the connection hetween dryness and disease incidence, the alssence of rainfall during July leing a distinctive characteristic of the year of clisease. The fact that the fuly rainfall in $19: 2$ exceeded that of the previous year only by slighty less than half an inch gives additional weight to a common observation, namely, that in nature what appear to he exceedingly slight clifferences in habitat serve effectively to predetermine the successful existence of an organism.

In many regions, hoth the leafhopper and the disease occur every year, the disease varying in severity and the leafhopper in numbers from year to year. So far as recorled information goes, it seenss to be rather generally true that a year of severe disease is alsin a year of abunrlant leafhoppers. From the weather records for the years of severe disease in such a region, one would expect consequently to obtain a hythergraphic representation of the themolyetic limits favorable to both the disease and the lea fhopper.

Such a diagran, smoothed, for Fresuo, California, is given in Figure $\therefore$ One would expect the normal themohyets of other regions to fall within this diagrans, and the probable truth of this expectation is shown also in Figure $i$ in which the monthly normal thermohyets for Sacramento and for southern California as a whole are inserted and actually fall within the smootherl or generalized diagran. On the other band. the hythergraph of a locality unsuited to both the insect and the discase ought not to conform in any important respect to the smooth diagran which represents the themohyetic characters of the normal habitat: and this is demonstrated by the hythergraph for the year 1!r? at Rurley. I daluo, superposed in Figure $:$ which shows not only a striking inconformity of trend but also a series of monthly thermolyyets falling. with :i exceptions, entirely ontside the natural range of the insect and the disease.

Although alumblance of leafhoppers and sererity of clisease nsually are coincident, they need not be always so: and one is led to sumise from this that there are certain themolyetic conditions that have a special influence upon disease incidence while certain others detemine insect abundance. The growing season of the crop, the characteristics of which bave been noticed already, is undombtedly the period of the year most influential with respect to the disease. whereas other periods of the year may be of greater significance with respect to the leafhopper: and it seens likely that the abundance of the leafhopper. while dependent in some measure upon the weather of spring and summer, probably is influenced to the 
330

Illinois Natural History Survey Bulletin

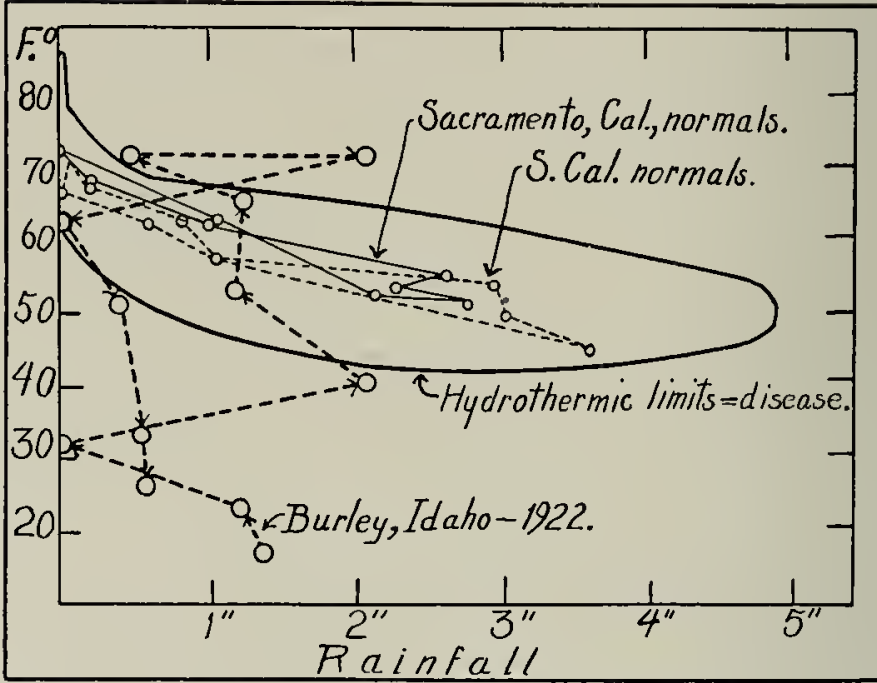

Fig. 7. The annual thermohyetic limits of regions in which "curlytop" is severe include the normal thermahyetic conditrons of a locality (Sacramento, Cal.) and of a region (southen California) where the disease is normally abundant but do not include or conform to a locality (Burley, Idaho) where the disease rarely occurs.

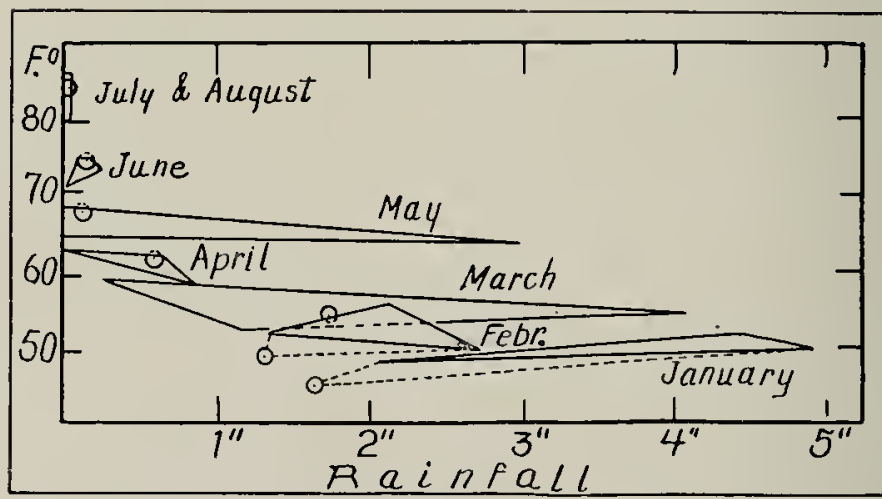

Fig. 8. In the Lake Tulane region of California, the thermehyets for January and February preceding seasons of leafhopper abundance fall in the warmer and wetter ranges of these months, as indicated by the location of the triangles with reaspect to the normal thermoliyets shown by the circled dots. 
greatest extent ly that of the hibernating or resting period. The range of weather for this period in years of insect abundance is shown by months in Figure $\&$ for the lake Tulare region in California, a typical hibermating locality which supplies an abunclance of the leafhoppers to surrounding territories during tavorable years. When the corresponding normal thermohyets for the same region are indicated on the hythergraph. it luecomes apparent that the themolyetic conditions of January and February in years of leafhopper abundance lie definitely within the wetter and warmer ranges of those months.

\section{THERMOHYETICS OF THL CLCLMBER BEETLES AXND THE B.ACTERIAL MILT OF MELONS}

The peculiar interdependence of the cucumber beetle. Diabrotica sittata Fab., and Bacillus trachciphilus (EFS) Sites. in the production of the bacterial wilt of encurbits affords an unusually good opportunity to show how the themohyetic characters of the natural habitat may be determined and how its variations influence in greater or less legree the activities of the organisms concerned in so complex a relation.

Muskmelons and the other members of the plant family Cucurbitaceate, excepting only the watemelon, are subject to a wilt clisease which results from the pathogenic activity of Bacillus trachoiphilus (EFS) Stev. In pure culture, and under the exacting conditions imposed by the bacteriologist in his lahoratory, this microbe shows a marked sensitivity to temperature, its ninimum requirement for growth being $166^{\circ} \mathrm{F}$. it optimum lying between $::^{\circ}$ and $86^{\circ}$, its maximum temperature for growth being $15^{\circ}$. and its thermal cleath-point lying at $110^{\circ}$. Within its host, it lives only in the xylem ducts of the water-conducting tissue and. unless it can gain access to them inmerliately after being introluced into the plant. it is not able to cause wilting. It is this peculiarity that loring cucumber beetles into the problem; for they serve as carriers of the bacterinm, and the punctures they make while feeding afford a means of entrance for the bacterium, directly from their mouth parts or indirectly from their droppings, into the xylen ducts. The only known place in which the bacterimm overwinters is the digestive tracts of the beetles.

Experimental evidence shows that both the striped cucumber beetle (Diabrotica aithata Fal).) and the 1 -spotted beetle (D. duodecimpunctata Say) act as carriers of the bacterinm: but field observations indicate that the striped beetle, which is the more abundant of the two in ordinary seasons, is the chief carrier.

The principal sufferes from the wilt disease are the muskmelon and its cultural modifications, the cantaloupe and the Honer Dew melon. The distribution of these crops is indicated in Figure ?, which shows the approxinate location of farms reporting 1 acre or more in the 1910 Census. Unfortunately, later clata are not arailable; but the reports of the $L$. S. Department of Agriculture. through its Bureau of Agricultural Economics. 


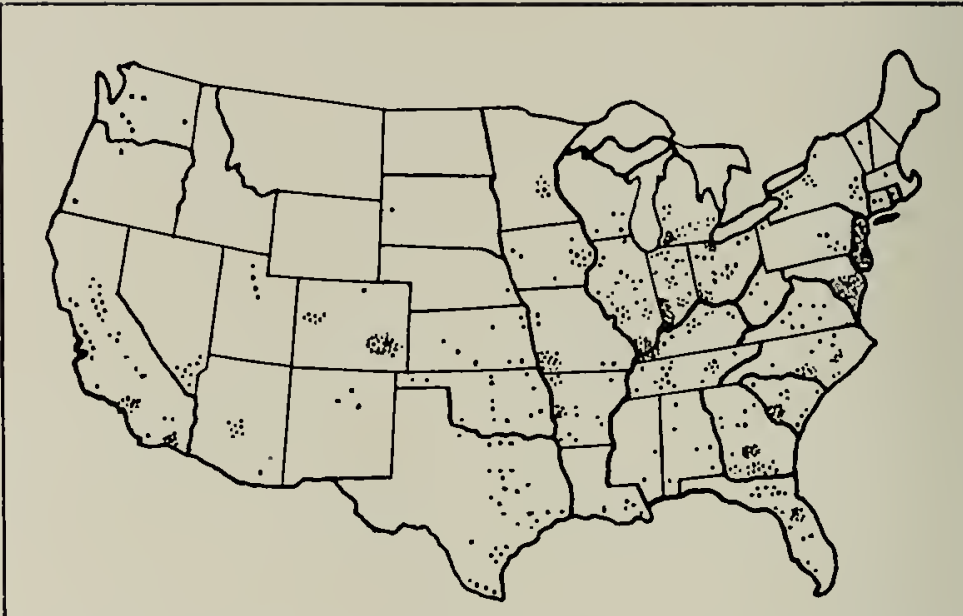

FIG. 9. Distribution of melon crops subject to bacterial wilt. Each dot represents 50 acres grown in 1909. (Redrawn from Finch and Baker's Geography of the World's Agriculture.)

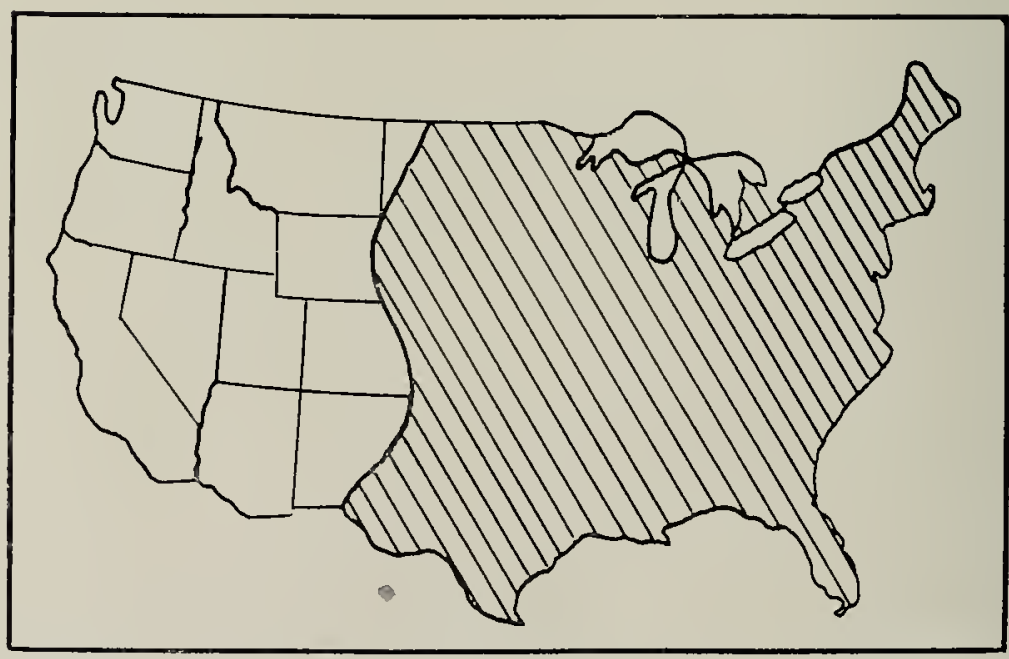

Flg. 10. Range of the striped cucumber beetle. (Redrawn from Chittenden.) 
indicate that the distribution of the crop has not changed greatly since that time, although the acreages have changed considerably in several states, and the map will serve to indicate where the disease and the beetles may be of economic importance.

Data showing exactly the linits of clistribution for either of the curcumber beetles are not available. Chittenden (3) gives the distribution of the striped beetle as the entire eastern two-thirds of the United States. illustrating his statement with the map reprorfuced in Figure 10; and the belief prevails among entomologists that there is virtnally a coincidence of clistribution for the two species. A search of literature and an extensive correspondence have failed to indicate that either beetle occurs ontside the North American continent, though both apparently range northward into Canada and southward into Mexico. Throughont this territory the average rainfall is 20 inches or more per year.

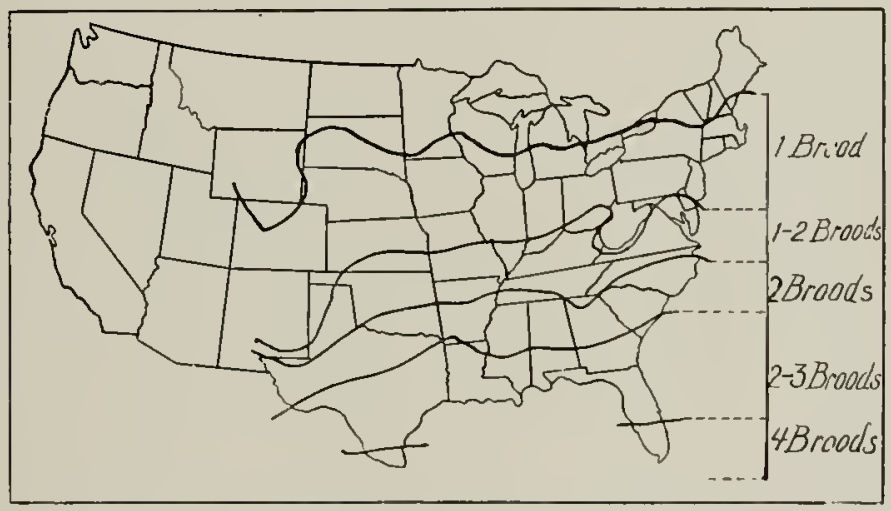

Fig. 11. Broad ranges of the striped cucumber beetle. This map is drawn from data in publications and from information secured by correspondence.

The general effect of temperature upon the striperl beetle is most readily scen in connection with the number of lnoods which it produces per year. Throughout the northern part of its range, there is but one brood, while sonthward the broods increase to two and exceptionally three, and at times there maty be as many as four in extreme sunthern Texas. The approximate geographic limits of these brood numbers are indicated in Figure 11 by the wavy horizontal lines, and it is, perhaps, not altogether an mexpected coincidence that these brood lines pretty definitely follow certain isotherms indicating mean annual temperatures. Where the mean temperature is annually less than $5.5^{\circ} \mathrm{F}$. the brood number is constantly one; between $5.0^{\circ}$ and $\left(50^{\circ}\right.$ there is one brood and ustrally a partial second; between $60^{\circ}$ and $6.5^{\circ}$ there are generally two broods; between $6,5^{\circ}$ and $: 0^{\circ}$ there are two broods and sometines a third; and where the annual mean temperature exceeds $: 0^{\circ}$ there may be four broods in a year. 
The available data on the occurrence of the bacterial wilt of cucurbits show it to be prevalent through a large part of the United States and to have occurred, at least in isolated instances, in Canada, Germany, Russia, the Transvaal, and Japan. The Canadian records can not be verifierl; the report from Russia is based upon a single wilted plant found in a greenhouse; those from Germany, the Transvaal, and Japan appear to be authentic, but are not accompanied by any statement as to the presence or absence of the cucumber beetles as carriers; hence it is apparent that these records of occurrence outside of the United States can not be marle the basis of a world-wide study. But records within the United States since 1918 are sufficiently complete to be fairly satisfactory. All of the states from which the disease has been reported since that year are shown by

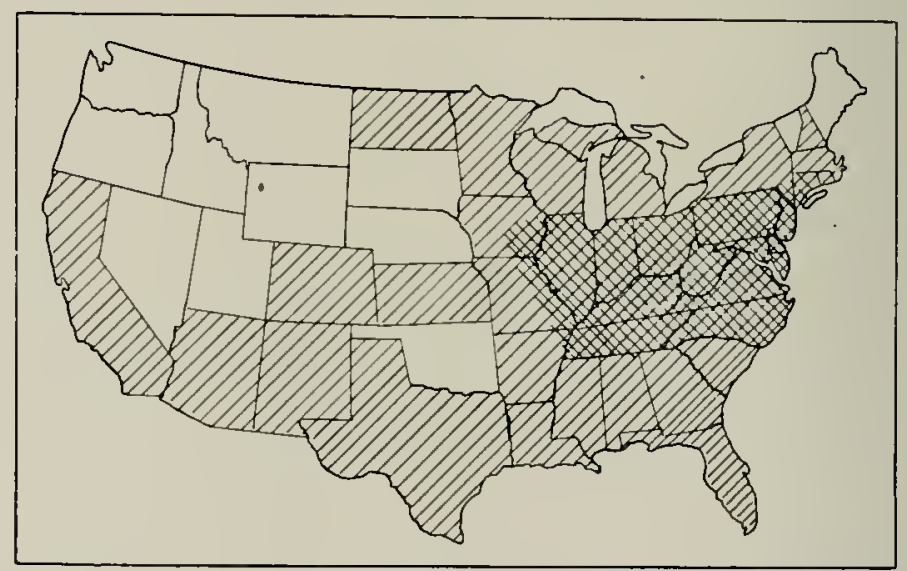

Fig. 12. Distribution of cucurbit wilt in the United States, compiled from Plant Disease Survey Reports. Diagonal lines mark the States from which this disease has been reported autheutically, and cross hatching marks the region from which reports of severe wilt usually come.

the hatching in Figture 12, while those states in which the disease is con1monly reported as serious are indicated especially by the cross hatching. Probably the disease, though present, is not a serious menace to the commercial crop throughout all of this territory, nor even throughout the territory in which it is commonly reported as being severe; rather, the regions of severity are probably rather localized and could be ascertained with fair accuracy by comparing Figure 9 and Figure 12.

Although the bacterial wilt has a distribution in the United States practically coextensive with that of the striped beetle, the territory throughout which it is most severe lies in a latitude ranging generally north of the southern boundary of Tennessee, while the territory in which the beetle appears to be most successful, as indicated by the number of generations 
per season, lies to the south of this line. The extent of the wilt's range is not limited northward in the United States, but the disease rarely is found in epidemic proportions much farther north than the southern third of Wisconsin. To the southward, it is linited, unless in exceptional cases. by the increase in temperature during the summer months.

Certain themolyetic characteristics of the coincident ranges of the beetles and the wilt are expressed hythergraphically in Figure 1:3. For convenience, in this case, the two halves of the year have been separated,

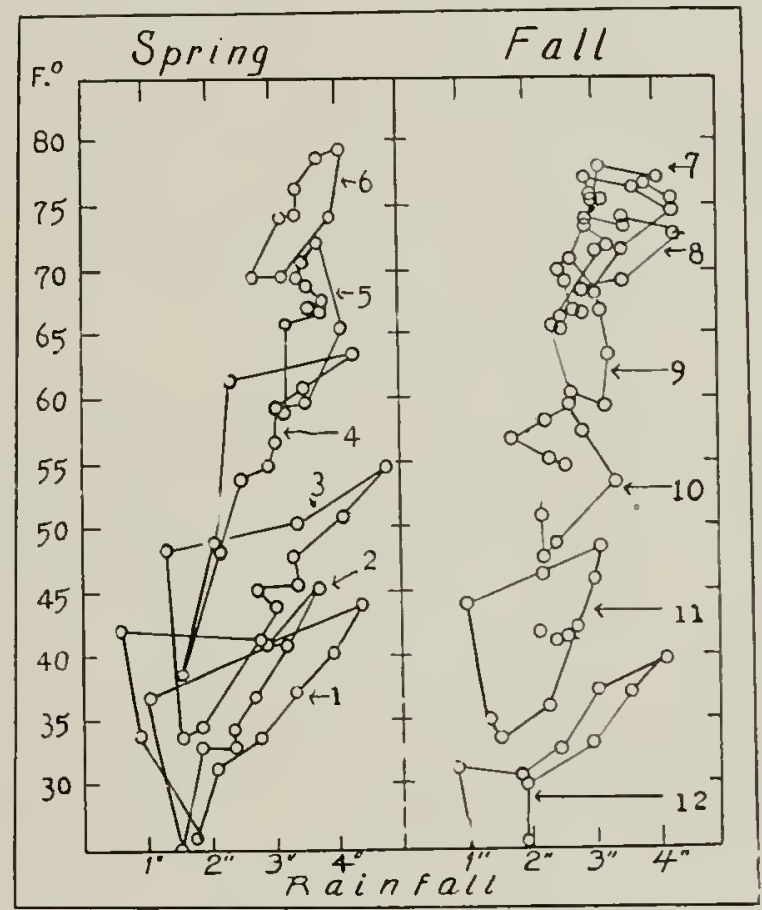

Fig. 13. Thermohyetic range, month by month, of a normal year for the coincident range of the striped cucumber beetle and cucurbit wilt. Circled dots show normal monthly thermohyets for selected States, and the months are indicated hy numbers.

and the thermolyets for certain States for each month of the year have been plotted, the outer points being connected by inclusive lines. Is this represents graphically the actual thermohyetic conditions reported by the II eather Bureau, it, of course, is not to be understood as showing the only conclitions under which either the beetles or the wilt can exist, but is to be considered as an inclusive statement of the average weather conditions prevailing in the territory in which these organisms occur. It is 
probable that a closer approximation of the limits of habitable climate for these organisms can be obtained by regarding the individual points for each month, as lying in undetermined ellipsoids and then connecting them by curved lines, thus substituting the rotund diagrams for the irregular polygons of Figure 13. Such an arrangement, shown in Figure 14, ought to be considered a reasonably comprehensive statement of the ranges, month by month, of the thermohyetic conditions under which the cucunber beetles and cucurbit wilt can exist successfully.

As was pointed out, the geographical limits of severe wilt are by no means as extensive as the territory throughout which it and the beetles range. It is ustually severe in the region in which the beetles generally have one to two broods per year, tending to be less so both to the north and the south. By arranging reports on wilt, secured from the mimeographs of the federal Plant Disease Survey and by special correspondence. into the five general classes, light, mild, destructive, moderately destructive, and severely destructive. I have found it possible to construct a hythergraph, using annual means of temperature and annual totals of rainfall for the regions and the years in which these degrees of disease were

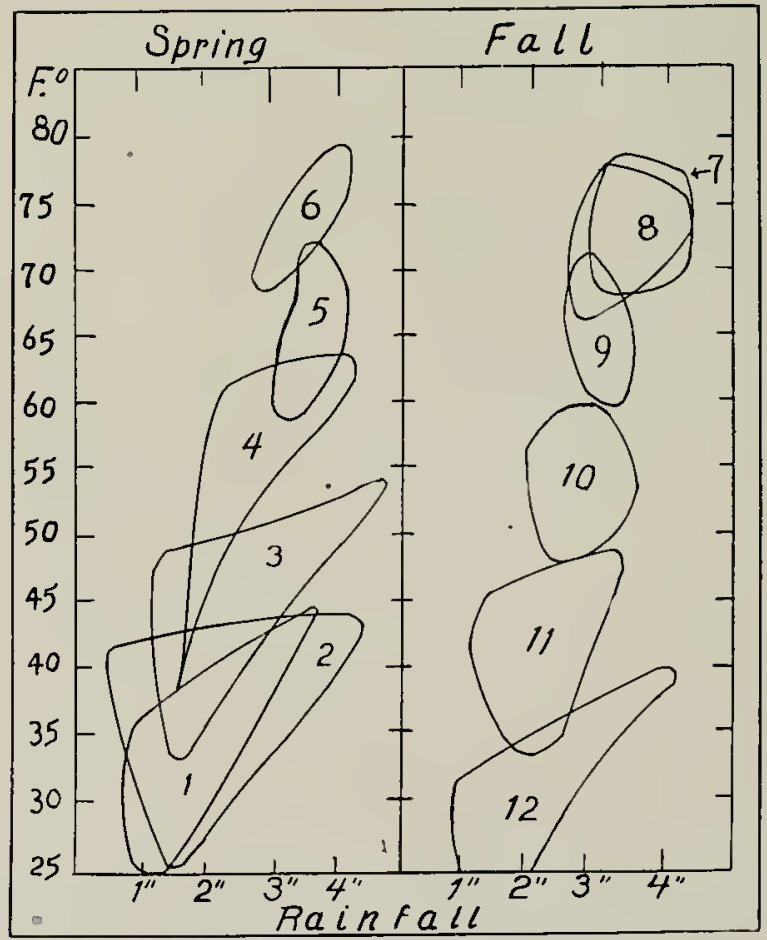

Fig. 14. Smoothed hythergraph drawn from Figure 13. The numbers indicate the months. 
reported to have occurred. In the resulting graph, given in Figure 15 , the outer range of thermohyetic combinations, marked $f$, includes those conditions under which the wilt occurs in light form; the thermolyetic limits bounded by the line marked $B$ include regions and years characterized by mild wilt and usually 1,3 , or 4 broods of beetles per year: within the limits marked $C$. the wilt is generally destructive, and the number of broods of beetles is either 1 , or 1 to 2 jer year; and the line marked $D$ incloses indubitable records of moderate and severe destruction. The differences in temperature and rainfall which distinguish these limits on the dry sicle of the graph are wide at first, but decrease as the intensity of disease attack increases; and the very slight difference between the limits $B$ and $C$ may be taken to indicate that at this point even very small changes in thermohyetic conbinations affect very greatly the intensity of the wilt attack.

As it is possille to be more specific regarding the wilt in Illinois. I give the following generalized comparison of the destructiveness of this dis-

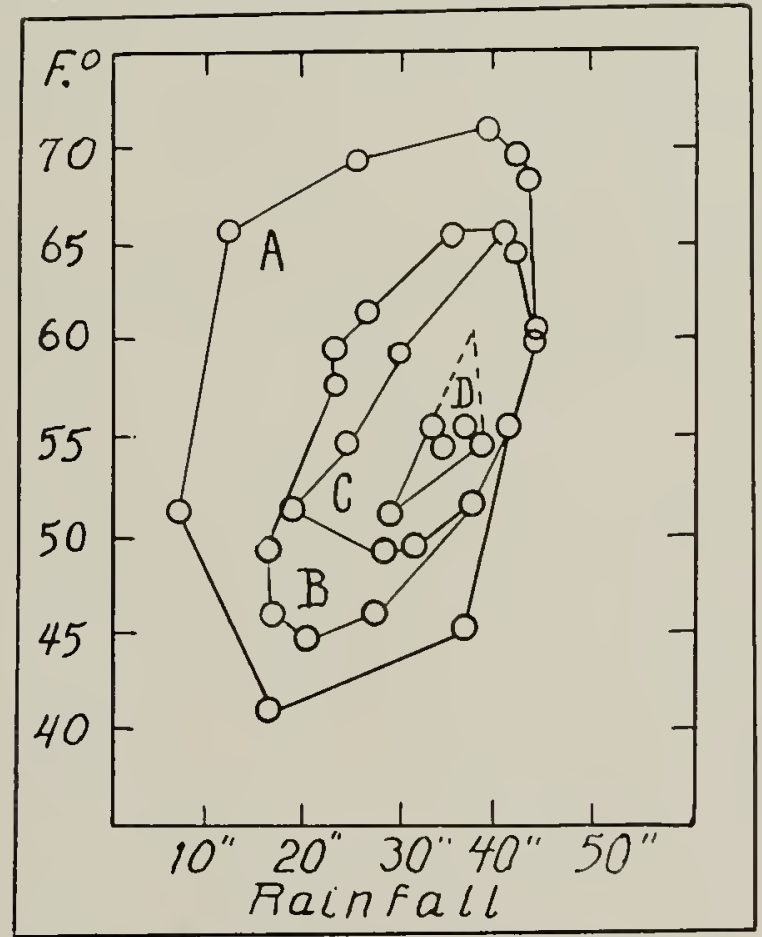

Fic. 15. Nean annual thermohyetic ranges under which various intensities of cucurbit wilt develop. In the region marlied $A$, the wilt occurs in light form; in $B$, it is mild but heavier than in $A$; in $C$. usually destructive; and in D, moderately to severely destructive. 

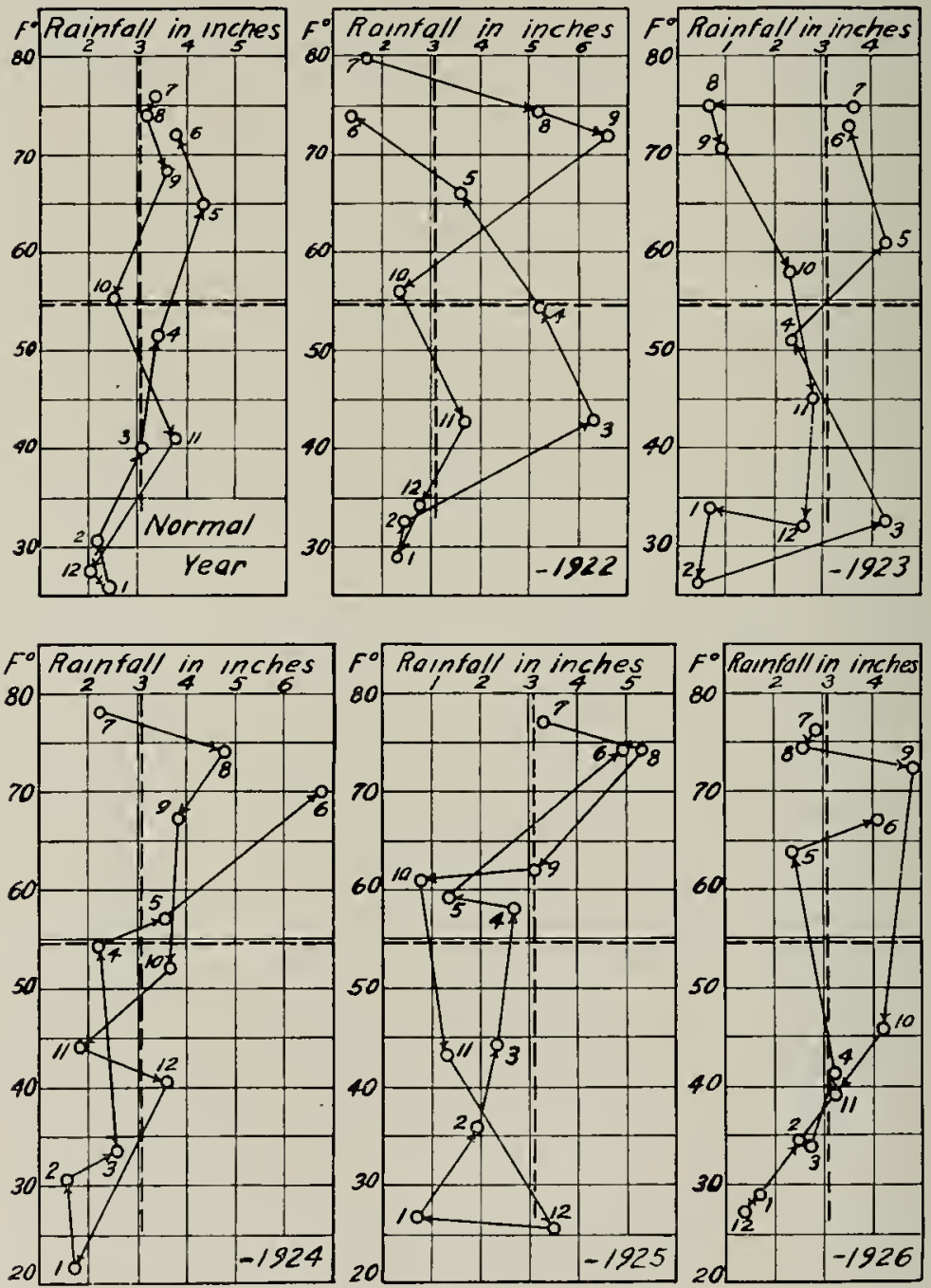

FIg. 16. Hythergraphs for Illinois, slowing the monthly thermoliyets for a normal year and for the years 1922-1926. The normal year falls near the 3 -inch rainfall coordinate; hut the year 1922 , when bacterial wilt was most severe, falls near the 4 -inch coordinate. The succeeding years, in which wilt was progressively less severe, fall more and more toward the dry side of the grapl. 
ease, as determined for the State ly our field examinations, using the same terms of distinction as above.

\begin{tabular}{|c|c|}
\hline Vear & Destructiveness of Cucurbit Wilt \\
\hline $1 ! 122$ & Moderately destructive \\
\hline $192: 3$ & Destructive.or moderately so \\
\hline $1 ! 94$ & Nildy destructive \\
\hline $1 ! 9 \cdot 5$ & Light to mild \\
\hline $1 ! 96$ & Light \\
\hline
\end{tabular}

A fairly steady decrease in abundance has occurred since 1912.2 . the ninimum being reacherl in $19: 26$. This is due, in part. to a more seneral use of an efficient beetle control cluring the last three years: but as the beetles were still abundant in many untreated fields. the difference is not attributable wholly to this cause. A comparison of the normal hythergraph of Illinois and hythergraphs for the year $192 \cdot ?$ ? to 19.26 , inclusive. these being shown in ligure 16, reveals marked differences in the thermohyetic trends of the years and in the montlyly themolyets--differences which are progressive and which correspont to the clecrease in amount of discase ly moving uniformly toward the dry side of the graph. The normal year. in llinois. lies close to the ordinate marking : inches of rainfall. The $1921-1 ! \cdot:)$ season, with restructive disease, falls roughly about the t-inch co-ordinate, although it shows a great fluctuation from this arerage during most of its months. The year 1 ! $1: 2-1$ !):? rather closely approximates the normal, falling quite near the 3 -inch line: $1593-1$ (1) 1 lies still farther to the dry sicle of the diagram. especially in the spring months: and the year $1921-1925$, with the exception of the summer. lies very close to the dry sirle, falling practically on the ?-inch rainfall line: while the year $1925-1 ! 9$ ? . which is not greatly different from a normal year, bears ont the rule.

\section{SIGNHIC.INCE OF HYTHERGRAIIS}

Hythergraphs such as 1 have uned as illustrations in the preceding pages have been employed in a numler of instances* to indicate habitats and probable habitat ranges for varion organisms. Originally devised by Ball in 1910, and first used ly Taylor in 1916. they have heen used since by Piere in connection with insect lite histories, by at least two persons to suggest the gengraphic ranges of insects. and by Huntington as the basis of an analysis of the relation of climate and weather to human health and progress. But none of these workers analysed the meaning of their graphs further than to draw such conclusions as were applarent upon inspection of the completed charts. It should he expected that diagrams such as these. which appleat to offer exceptionally plain evilence of the dependence of organisms upon climate. and of the marked limitations placel njon organisms by variations in thermolyetic conditions, would be founded npon certain natural laws. or have such a close relation to them that sufficient study would reveal some basic facts regarding all habitats.

* Ser the appended hibliography. 
As it is used now, the hythergraph takes two forms. As they seem to be distinct, both in their construction and in their use, so each has its own significance in interpreting biotic phenomena.

The first type, exemplified in Figure 16, slows diagrammatically the progress, from one month to another, of individual or grouped thermohyets attending any given phenomenon. Beyond the fact that it pictures conditions more simply and clearly than words, and so makes comparison easy, it has no significance.

The second type is represented especially in Figure 15. In its construction, a considerable number of thermohyets are plotted in such a way as to indicate, when they are sufficiently numerous and accompanied by good correlative data, what specific conditions govern, or are related to, the occurrence of definite phenomena. When such a diagram has been completed, it is usually true that the thermohyetic conditions productive of successive degrees of phenomenon development, such as amounts of disease, healthiness, and the like, can be defined quite exactly by connecting in series the plotted thermohyets in accordance with the correlative data. The resulting lines, called "isopracts" by Huntington, are roughly circular, elliptical, or ovoid, and usually are eccentrically arranged.

These relations may be illustrated concretely with data and a modification of a diagram which I have used in another connection (20). As the result of careful surveys of wheatfields in lllinois, numerical indexes showing the destructiveness of leaf rust (Puccinia triticina Erikss.) were obtained for each of five years, with the intention of determining from them what relation the yearly mean temperature and the total rainfall bore to the intensity of the rust attack. The data at hand were those given in the following table:

\begin{tabular}{c|c|c|c}
\hline \hline Year & $\begin{array}{c}\text { Destructiveness } \\
\text { index }\end{array}$ & $\begin{array}{c}\text { Nean temperature } \\
\text { of the rust years }\end{array}$ & $\begin{array}{c}\text { Total rainfall of } \\
\text { the rust years }\end{array}$ \\
\hline & 50.3 & 54.8 & 41.73 \\
1922 & 31.3 & 53.1 & 32.69 \\
1923 & 19.1 & 51.9 & 38.74 \\
1925 & 17.1 & 53.0 & 31.15 \\
1926 & 11.2 & 51.3 & 35.15 \\
\hline
\end{tabular}

Neither by inspecting the table nor by employing the usual graphic methods can one demonstrate the relation that actually exists between the rust indexes and their accompanying thermohyets; but it can be demonstrated by the hythergraphic method with the diagram given in Figure 17. In constructing this diagram, a preliminary graph was made, upon which were plotted the thermohyets for each index of the rust; and, as these seemed to fall into two well-defined series, the trend of each series was marked by a dotted line. The relative values of the temperature and rainfall scales were then adjusted by the simple expedient of reclrawing the 
dotted lines at $45^{\circ}$ angles to the axes and then locating on them the points on the old lines by swinging intersecting ares with a compass. The result was such as to indicate that a difference of $1^{\circ}$ of mean annual temperature would equal, in its effect, an approxinnate difference of 5 inches in total annual rainfall.*

Having thus located the trend lines, and having replotted the thermohyets accurately. as they are shown in Figure $1 \%$, I could readily see that the trend lines lay one on each side of the line of perfect correlation. But neither in the data nor in the graph is there any indication of the probable location of this line or of the line of absolute non-correlation. It seemed to me reasonable to suppose, however, that, as Illinois appeared to be fairly representative of the rust's habitat, these lines ought to have some rather close relation to the normal thermohyet for that state: and this thermohyet, therefore. I plotted at the intersection of the nomal mean annual temperature line of $52^{\circ}$ and the normal total annual rainfall line of $: 36.42$ inches. Through the point thus located, I drew tentative lines of correlation and non-correlation; and, by good fortune, I found the

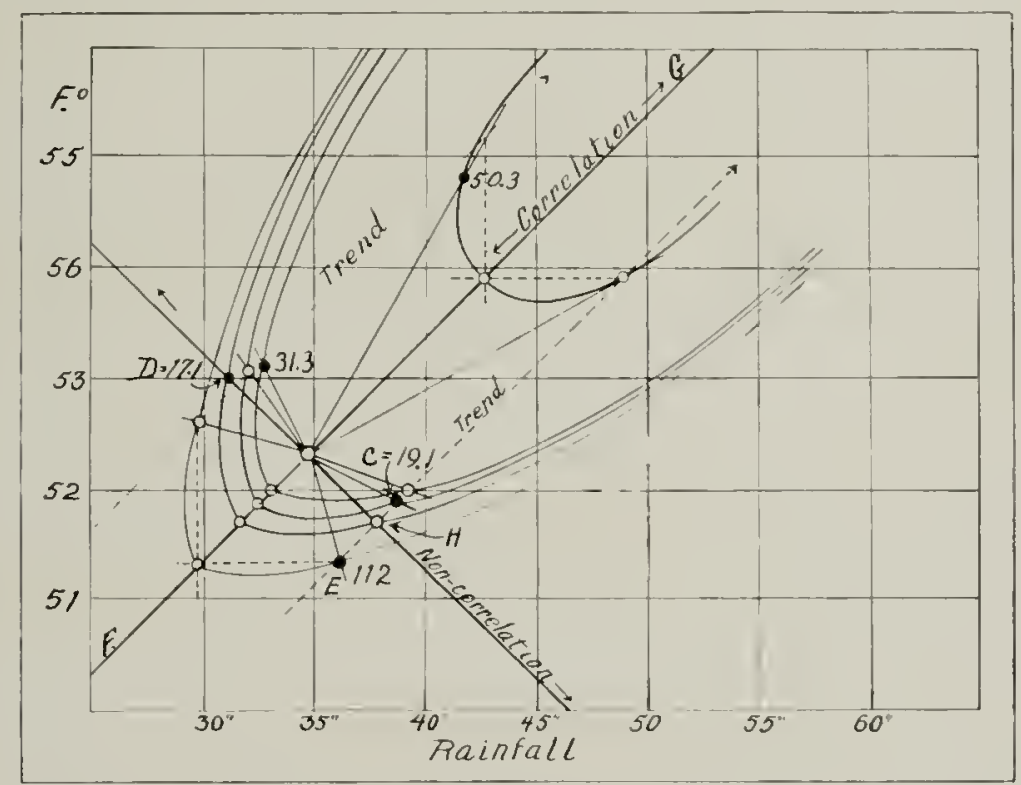

FIG. 17. Hythergraph indicating the relation of the intensity of wheat leaf rust attacks to annual thermohyets in Illinois. The method used in constructing this graph is described in the text.

* It appears from a hythergruph given by Griffil Taylor wn page 271 of his "Euvirominent and Face" (Oxford Uuiversity Press. 1927), that survical of infants in Australia the converse of increase in prevalence and fatality of infant diseases-increases as both temperature and rainfall derease but Tayln has not determined the relative effects of the two elments. 
latter passing so near the point $D$, which had a predetermined rust index of $1 \% .1$, and cutting the lower trend line at $\mathrm{H}$-which appeared upon inspection to lie very close to the point where, between $E$ and $C$ (which had determined indexes of 11.2 and 19.1 , respectively) one would expect to find an index of 1\%.1 - that I took this to indicate witl fair certainty: first, that ny hypothetical line of non-correlation lay so close to the real line as to serve the same purpose; and, secondly, that the line of true correlation must consequently be situated parallel to the two trend lines and very nearly midway between them. $I$, therefore, replaced the tentative correlation line, which at first I had drawn througl the normal Illinois thermohyet, with another ( $F-G$ in the figure) and proceeded to locate all given rust indexes not only on the trend lines but also on the correlation line in accordance with the following reasoning.

It seemed clear to me, in view of certain other clata I had at hand, that the rust fungus might very well be regarded as having physiological properties similar to those long since proved for other organisms and that if I followed, deductively, for my organism the same steps as had been traversed experimentally for others, I ought to arrive at a tenable, though necessarily quite general, hypothesis of thermohyetic relations. I considered, therefore, that if a complete corrclation between increasing temperature and increasing rainfall, singly or in combination, and disease increase were assumed to exist throughout all ranges of temperature and rainfall, the graphic expression of such a condition would be a straight diagonal line of the general formula $y=k x$, when $y$ represented increase in disease and $x$ increase in either temperatule or rainfall or both. With this assumed, it is apparent that all the various combinations of temperature and rainfall capable, when acting together, or producing a given amount of disease would be shown by a rectangular hyperbola of the general formula $x y=k^{2}$.

Of course, it has been determined experimentally many times and for a great diversity of organisms that, though appearing to be true within a linited range of conditions, no such fine regularity as the above exists. Instead, we have conne to expect in place of the straight diagonal, a curve which rises slowly at first, then rapidly and quite regularly through most of its length, until it reaches an optimun and thereafter falls precipitately to a maximum. Such a curve often has no definite formula, though its type is usually indicated as $y=f(x)$. The rapidly rising portion of this curve, though approximating the straight-line diagonal, never conforms to it completely; for there is continual readjustment throughout its length to the increasing, decreasing, and inhibiting effects of the changing environmental factor. Consequently, the curve for a constant amount of disease, when plotted with tenperature and rainfall as the axes, can not be a rectangular hyperbola; for, when the amount either of temperature or of rainfall becomes inhibitive, that effect must be counterbalanced by the addition, upon the curve, of an increasing effect from the other; and the curve, though approaching the liyperbola in its mid-region, is macle, toward its extremities, to swing away from the axis. The result is an 
ellipse of the type to which the general formula $a x^{2}+b y^{2}+c x y+d x$ $+c y+f=o$ usually applies.

Returning then, to my rust problem, I was confident that all the points denoting any given anount of rust attack onght to lie in an isopract of an elliptical or ovoid shape, the long axis of which would be the line of perfect correlation: and, having demonstrated the position of this line as midway between the trend lines, I saw that for every themohyet of linown rust value I could determine geometrically two other thermolyets having, bypothetically, the same rust value, one upon the opposing trend line and one upon the correlation line, for I conld measure lyy running a line from a thermolyet of known value to the junction of the correlation axis, an angle which would determine the position of another line clrawn from this junction to cross the other trend line at a point geometrically equivalent to the first and, with two such points located, I could determine their effuivalent upon the correlation line lyy marking the point where it and their respective temperature and rainfall values conincided. By this means. I was able to increase 11 y original five points of data to fifteen, having three points to clenote the location of the isopract for each of five known rust indexes, and, after drawing a large series of partial ellipses through each of these five sets, I selected from each series the one which in conjunction with all the others, seemed most apt to fulfill the conditions imposed.

It is not to he supposed that I considered these isopracts, so hivothetically constructed, as by any means proved; yet the verisinilitude letween the chart thus developed and the hythergraphs so readily obtained with more abmalant lut less accurate data, together with the fact that all the requirements of natural processes appeared to have been satisfied. led me to believe that I had obtained a clear, though general, picture of the relation of rust to annual themohyetic conditions and that I had, at the same time, shown why hythergrajhs similar to Figure 1; do inclicate so clearly the limitations imposed by climatic conditions upon the occurrence and clistribution of organisms and the influences of fluctuations in weather upon the success of an organism in a given region.

The ellipses, or isopracts, of an hythergraph, since they ustrally mark measured degrees in the manifestation of some natural phenomenon, are comparable to the contour lines used by physiographers to show differences in altitude on plane-surface maps. Indeed, to carry the physiographic comparison still farther, the hythergraph may be regarded as a representation, in a single plane, of three of the factors which enter into the composition of a natural phenomenon; for the flat surface has width and length, and the isopracts show height. Though two distinct elements, temperature and rainfall, are shown by the flat surface, their reative values, with respect to the third dimension ancl to each other, can be determined readily by means of correlation charts and graphs, and the two scales can be arranged in units of efunal value; that is, with a series of increases in one element there must be corresponding increases in the other, and a plotting of points resulting from these increases should deter- 
mine a line lying at an angle of exactly $45^{\circ}$ from either the abscissa or the ordinate.*

Because they are considered to have a definite relation to the adjusted factors denoting width and length, the isopracts should be smooth in outline and regular in shape; but in practice they often are not so- a fact for which the explanation may be advanced that, as there are other elements, such as sunlight, wind, and the like, acting also, their influence will be shown in the isopracts in much the same manner as the action of wind and water as erosive agents appears in contour lines.

This conception of the inter-relation of the weather elements and natural phenomena as a 3-dimensional subject seems to me to be so important, not only as a basis for understanding and interpreting the effects of weather and climate upon the distribution and abundance of organisms but also as a funclamental law bearing clirectly upon the results of precise laboratory experimentation, that I have ventured to embody it concretely in the perspective drawing shown as Figure 18 . The data from which this figure is formed are the same as those used for Figure 1\%, except that, in place of the rather generalized terms previously used, I have substituted concrete limits to the amount of disease, designating somewhat arbitrarily the circle $A$ of Figure 15 as having 5 per cent diseased plants; circle B, 20 per cent; circle C, 35 per cent; and circle D, 50 per centthereby providing for every point shown on Figure 15 a datum of 3 items, one of temperature, one of rainfall, and one of disease abundance, by means of which four planes of the cone in Figure 18 were very easily located. The outlines of the cone and the smoothed circumferences of the four planes are, of conrse, drawn entirely by inference; but it seems to me from this figure that the relating of a natural phenomenon, in all its degrees of manifestation. to any two outstanding factors of environment involves measurements expressible, as a whole, in a three-dimension diagran, the resulting object being conic in form.

One characteristic of this cone appears to have a rather important significance when results obtained by experimentation, under controlled conditions, upon the reaction of an organism to an environmental factor are made the basis for predicting any event in nature. The cone is not symmetrical. In profile, it has upon one side an extensive base, which rises slowly, at first almost imperceptibly, from the plain; as the altitude increases, the gradient of the slope also increases, until the peak rounds it off; and, on the other side, the downward slope falls away very steeply and merges abruptly into the plain. The shape of this profile is similar in all respects to the characteristic curve of response that is secured experimentally when one factor is held constant and the other is varied: indeed, from its shape and composition, it seens apparent that the cone, if cut into an infinite number of longisections, would furnish exactly the same set of curves as would be secured from an equal series of experiments.

* The proof of this statement would require a recapitulation of a consiclerable part of the mathematical theory relating to the standardization of measurements, which, though simple, lies outside the scope of this paper and therefore is not given in detail. 


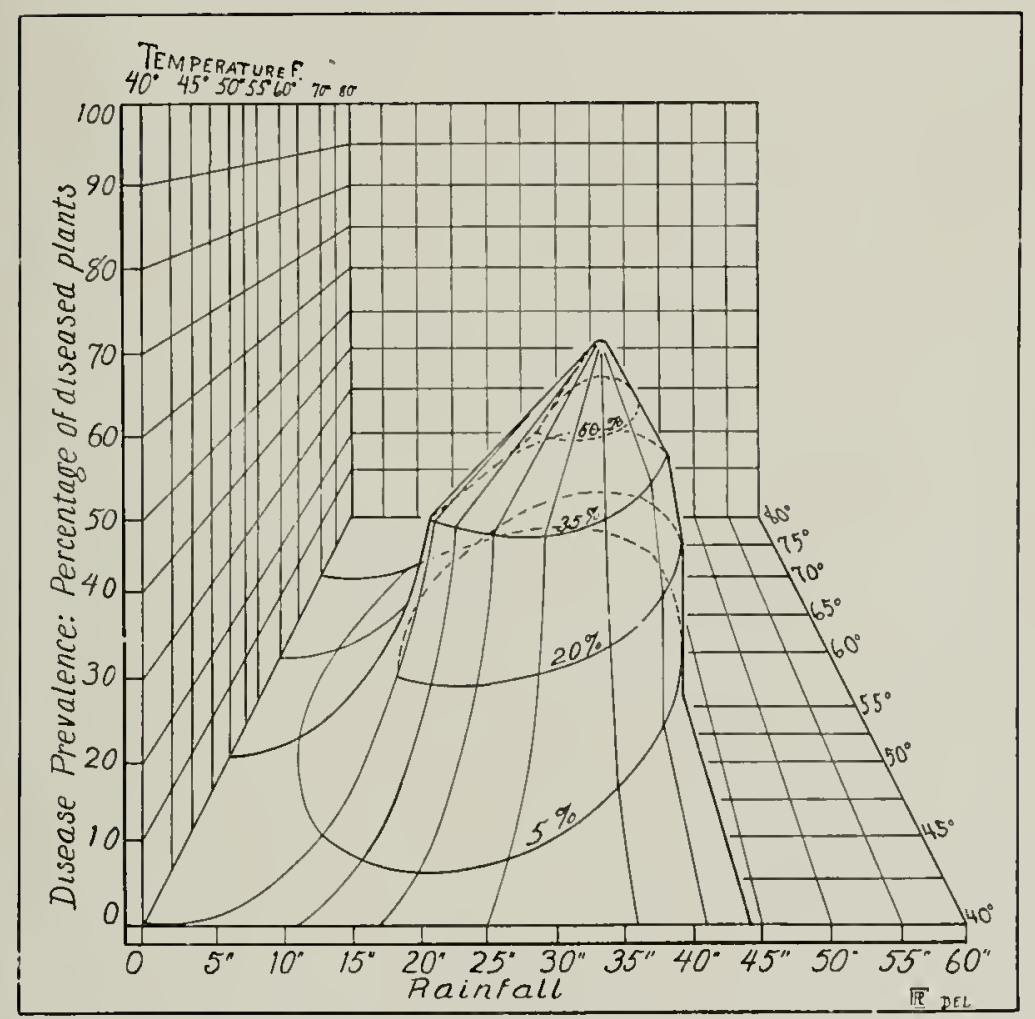

Fig. 1s. Three-dimensional graph indicating the interrelation of annual mean temperatures, totals of anmual rainfall, and the severity of disease attack. This is a reconstruction of Figure 15. 


\section{BIBLIOGRAPHY*}

1. BALL, E. D. The beet leaflopper and the curlyleaf disease that it transmits. Utah Agr. Exp. Sta. Bull. 155. 1917.

2. B.Ll, J. Climatological diagrams. Cairo Sci. Jour. 4:280-281. 1910.

3. Cinttendex, F. H. The striped cucumber beetle (Diabrotica vittata Fab.) and its control. U. S. Dept. Agr. Farmers' Bull. 1038. 1919.

4. Cour, W. C. Studies in the physical ecology of the Noctuidae. Minn. Agr. Exp. Sta. Tech. Bull. 12. 1923.

5. _ _ _ The distribution of the pale western cutworm, Porosagrostis orthogonia Morr.: a study in physical ecology. Ecology 5:60-69. 1924.

6. —— Distribution of the alfalfa weevil (Phytonomus posticus Gill.) A study in physical ecology. Jour. Agr. Res. 30:479-491. 1925.

7. Fluxuers, V. B. The use of charts and graplis in the study of climate. No. Weather Rev. 50: 481-484. 1922.

8. HASKEL, R. J. AND JESSIE I. Wood. Diseases of vegetable and field crops in the United States in 1926. Plant Disease Reporter. Supplement 54: 259 . fig. 24.1927.

9. Huxtrigtox, E. Civilization and climate. New Haven, Yale University Press. 1915.

10. - Graphic representation of the effect of climate on man. Geog. Rev. 4:401-403. 1917.

11. World power and evolution. New Haven, Yale University Press. 1919.

12. Jounsox, E. L. Relation of sheep to climate. Jour. Agr. Res. 29:491-500. 1924.

13. Martin, W. H. Late blight of potatoes and the weather. New Jersey Agr. Exp. Sta. Bull. 384. 1923.

14. Pierce, W. D. A new interpretation of the relationships of temperature and hunidity to insect development. Jour. Agr. Res. 5:1183-1191. 1916.

15. Suelford, V. E. Physiological life histories of terrestrial animals and modern methods of representing climate. Trans. Ill. St. Acad. Sci. $13: 257-271.1920$.

16.

An experimental investigation of the relations of the codling moth to weather and climate. 1ll. State Nat. Hist. Surv. Bull. $16: 311-440.1927$.

17. TAYLok, G. Control of settlement by humidity and temperature. Commonwealth Bur. of Meteorology (Australia). Bull. 14. 1916.

18. _ _ Geographical factors controlling the settlement of tropical Australia. Queensland Geog. Jour. 32-33: 1-67. 1918.

19. __ The settlement of tropical Australia. Geog. Rev. 8:84-115. 1919.

20. TeHon, L. R. Epidemic diseases of grain crops in Illinois: 1922-1926. Ill. State Nat. Hist. Surv. Bull. Vol. 17 (Art. I). 1927.

21. Varaey, B. M. Some further uses of the climograph. Mo. Weather Rev. 48:494-497. 1920 .

* Citations given here but not mentioned in the text are included in order to furnish suggestive source references to readers interested in weather diagrams. 